\title{
SURVEI IMPLEMANTASI INFORMATION AND \\ COMMUNICATION TECHNOLOGY (ICT) DALAM \\ PEMBELAJARAN BAHASA INGGRIS DI SMA SE-KABUPATEN GORONTALO
}

\author{
Oleh: Indah Wardaty Saud ${ }^{1}$, Dahlia Husain ${ }^{2}$, Adimawati Helingo ${ }^{3}$ \\ ${ }^{(\mathbf{1}, \mathbf{2}, \mathbf{3})}$ Program Studi Sastra Inggris, Fakultas Ilmu Budaya, Universitas Muhammadiyah Gorontalo \\ (UMG) \\ Jl. Prof. Dr. H. Mansoer Pateda, Pentadio Timur, Kab. Gorontalo \\ Web: http://umgo.ac.id email: univ.muhammadiyah_gorontalo@ymail.com Telp (0435) 881135
}

\begin{abstract}
Abstrak
Penelitian ini bertujuan untuk mengetahui pengaruh implementasi Information and Communication Technology (ICT) sebagai media dan sumber belajar dalam pembelajaran Bahasa Inggris terhadap hasil belajar bahasa Inggris siswa SMA. Penelitian ini dilaksanakan di sepuluh SMA Kabupaten Gorontalo, terdiri dari tujuh SMA negeri dan tiga SMA swasta. Metode yang digunakan adalah metode survei dengan pendekatan Cross Sectional Study. Sample 250 responden siswa SMA kelas XI diambil dari sepuluh SMA Negeri dan Swasta sebagai representasi dari populasi siswa SMA kelas XI yang ada di SMA Kabupaten Gorontalo. Sample ini diperoleh dari teknik probability sampling. Data diperoleh dengan metode kuesioner yang didistribusikan kepada 250 responden mengenai persepsi Imlementasi ICT sebagai media dan sumber belajar, dan metode dokumentasi terhadap hasil belajar siswa pada mata pelajaran Bahasa Inggris yang diperoleh dari nilai Ujian Tengah Semester, semester genap tahun ajar 2017/2018. Data kemudian dianalisis menggunakan metode Regresi Linear Sederhana untuk mengetahui pengaruh Implementasi ICT terhadap hasil belajar siswa. Hasil penelitian ini menunjukkan bahwa analisis yang dilakukan dengan korelasi Product Moment (rxy) antara implementasi ICT (X) dengan hasil belajar siswa kelas XI (Y) diperoleh koefisien korelasi sebesar 0.604 nilai yang kuat. Hasil ini menunjukkan hubungan atau pengaruh positif dan signifikan antara Implementasi ICT sebagai media dan sumber belajar dalam pembelajaran Bahasa Inggris dengan hasil belajar Bahasa Inggris siswa kelas $X I$. Nilai $R$ Square atau nilai koefisiensi determinasi sebesar 0,365 yang berarti bahwa variabel dependen (Hasil Belajar) mampu dijelaskan oleh variabel independen (Implementasi ICT), sebesar $36,5 \%$, sebaliknya sebesar 63,5\% dapat dijelaskan oleh faktor-faktor lain yang tidak diikutsertakan dalam penelitian ini.
\end{abstract}

Kata Kunci: ICT, Media dan Sumber Belajar, Hasil Belajar Bahasa Inggris.

\section{Pendahuluan}

Era globalisasi memberi perubahan besar dalam setiap sendi kehidupan ditandai dengan meningkatnya pertumbuhan Information and Communication Technology (ICT). Pesatnya pertumbuhan ICT telah merubah pola-pola komunikasi dan distribusi informasi tanpa batas wilayah, Negara, atau waktu dan ruang. Berkaitan dengan dunia pendidikan, sekarang ini, ICT digunakan sebagai alat/media bantu yang tidak hanya untuk mentransfer materi tapi juga untuk menyebarluaskan informasi mengenai materi tersebut.

Jenis dan fungsi ICT dalam pembelajaran sangat beragam, mulai dari penggunaan $O H P$, power point, email, games simulation, internet, dan Facebook. ICT juga digunakan sesuai dengan fungsi dan kapasitas dalam proses pembelajaran yang disesuaikan dengan silabus dan rancangan pembelajaran. ICT bisa digunakan sebagai media pembelajaran yang memberi penekanan pada penyampaian informasi atau isi (materi) secara online yang lebih lanjut dikenal dengan e-learning; menyediakan seperangkat alat yang dapat memperkaya nilai belajar traditional (textbook); tidak mengganti sistem belajar klasikal, tetapi memperkuat model belajar tersebut melalui pengayaan informasi tentang materi; memberikan nuansa pembelajaran yang sangat bervariasi, tergantung pada bentuk isi serta alat penyampaian informasi atau 
pesan-pesan pembelajaran dan gaya belajar. Apabila materi dikemas dengan baik dan didukung dengan alat penyampai informasi dan gaya belajar yang serasi, maka ICT dijadikan media dan sumber belajar untuk membantu kualitas pembelajaran bahasa Inggris. Dikemukakan oleh Miarso (dalam Kariman \& Mulia, 2012), ICT sebagai media berfungsi untuk mengatasi hambatan dalam berkomunikasi, keterbatasan fisik dalam kelas, serta sikap pasif dari siswa. ICT sebagai alat untuk mentransfer informasi/materi ajar sehingga siswa bergairah dalam belajar, memungkinkan interaksi yang lebih langsung antara siswa dengan lingkungandan kenyataan, dan memungkinkan belajar sendiri-sendiri menurut kemampuan dan siswa. Pendapat ini juga didukung oleh Cahyono \& Widiati (2007) yang menjelaskan bahwa mengaplikasikan internet dalam pembelajaran bahasa Inggris merupakan hal yang penting dalam bidang akademi dan bisa menjadi salah satu solusi untuk masalah dalam pembelajaran Bahasa Inggris sebagai Bahasa Asing.

\section{Pengaruh ICT sebagai Media dan Sumber Belajar terhadap Hasil Belajar Bahasa Inggris}

Penelitian-penelitian mengenai pemanfaatan ICT dalam pembelajaran bahasa Inggris, membuktikan bahwa ICT berpengaruh positif signifikan terhadap motivasi dan hasil belajar. Penelitian tersebut antara lain; yang dilakukan oleh Sabar \& Rahman (2011) mengenai penggunaan web (e-learning) dalam proses pembelajaran bahasa Inggris di Briton International English School Makassar. Penelitian ini menunjukkan nilai tambah yang didapatkan siswa dengan menggunakan e-learning yaitu para siswa mendapatkan lebih banyak informasi dan bahan belajar yang terkini (up to date) dengan mudah, lebih cepat dan detail (jelas), dan keterampilan berbahasa Inggris para siswa dapat berkembang khususnya kapasitas belajar ini akan lebih baik yang pada gilirannya akan memberikan hasil yang lebih baik. (Cahyono, 2011).

keterampilan reading, writing,vocabulary, dan grammar.

Penelitian lainnya juga dilakukan oleh Sudrajat \& Permatasari (2013) tentang Pembelajaran multimedia (Macromedia Flash MX) untuk meningkatkan kualitas belajar siswa dalam mempelajari bahasa Inggris kelas XI di MAN 2 Kota Cirebon. Hasil penelitian yang dilakukan dengan memanfaatkan multimedia pembelajaran bahasa Inggris adalah adanya peningkatan kualitas belajar siswa dengan dibuktikan pada nilai yang diperoleh oleh siswa kelas XI IPS 2\&3 MAN 2 Kota Cirebon. Kariman \& Mulia (2012) mengenai pemanfaatan WebBlog sebagai media pembelajaran untuk meningkatkan hasil belajar Bahasa Inggris. Hasil dari penelitian ini adalah terdapat interaksi antara media pembelajaran dengan kemampuan awal siswa dalam mempengaruhi hasil belajar bahasa Inggris siswa Kelas IX SMP Laksamana Martadinata Medan.

Dari uraian di atas, pembelajaran Bahasa Inggris yang difasilitasi oleh ICT sebagai media maupun sumber belajar berpengaruh signifikan terhadap prestasi/hasil belajar siswa. Didukung oleh teori-teori dasar dan beberapa publikasi ilmiah serta hasil penelitian. Oleh karena itu, pemanfaatan ICT sudah saatnya dioptimalkan dalam pembelajaran, termasuk di sekolah menengah atas di Indonesia. Berdasarkan data ini, maka peneliti tertarik menginvestigasi implementasi ICT sebagai media dan sumber belajar dalam Pembelajaran Bahasa Inggris di SMA se-Kabupaten Gorontalo, guna mendapatkan informasi tentang bagaimana implementasi ICT sebagai media dan sumber belajar dalam pembelajaran Bahasa Inggris, dan bagaimana pengaruh implementasi tersebut terhadap hasil belajar Bahasa Inggris siswa. 
Implementasi ICT dalam pembelajaran melibatkan seluruh sistem dalam sebuah sekolah mulai dari pimpinan/ kepala sekolah, guru, staff, dan juga siswa, maka penelitian ini membatasi fokus masalahnya hanya pada persepsi atau opini siswa tentang implementasi ICT sebagai media dalam pembelajaran Bahasa Inggris. Persepsi siswa tersebut kemudian dihubungkan dengan hasil belajar siswa dalam mata pelajaran Bahasa Inggris sehingga diperoleh data tentang pengaruh penggunaan ICT terhadap hasil belajar siswa.

\section{Metode}

Penelitian ini dilaksanakan di 10 (sepuluh) SMA di kabupaten Gorontalo. Populasi dalam penelitian ini adalah seluruh siswa di sepuluh SMA Kelas XI di Kabupaten Gorontalo berjumlah 2513 siswa, sedangkan yang menjadi sampel adalah $10 \%$ dari populasi yaitu 250 siswa kelas XI SMA dari sepuluh SMA (tujuh SMA negeri dan tiga SMA swasta). Penarikan sample menggunakan teknik probability random sampling. Pemilihan sample siswa kelas XI dengan tujuan bahwa pengalaman belajar bahasa Inggris siswa kelas XI sudah lebih lama dibandingkan kelas $\mathrm{X}$ sehingga mereka bisa memberikan persepsi mengenai implementasi ICT sebagai media dan sumber belajar pada pembelajaran Bahasa Inggris. 
Penelitian ini menggunakan metode survei kuantitatif yakni penelitian mengambil sampel dari satu populasi dan menggunakan kuesioner sebagai alat pengumpul data pokok. Pendekat0an penelitian ini adalah Cross Sectional Survey, dimana penelitian ini untuk mengetahui isu yang bersifat temporer dengan pengumpulan data cukup satu kali. Dengan demikian, peneliti mengumpulkan data dari hasil survei satu kali melalui angket yang dibagikan kepada 250 sampel siswa di sepuluh SMA se Kabupaten Gorontalo. Angket yang disebarkan kepada sample sebagai responden bertujuan untuk memperoleh data mengenai implementasi ICT sebagai media dan sumber belajar dalam pembelajaran Bahasa Inggris di SMA se Kabupaten Gorontalo. Sedangkan data mengenai hasil belajar siswa kelas XI pada mata pelajaran Bahasa Inggris diperoleh melalui dokumentasi nilai ujian Tengah semester, semester genap 2017/2018. Selanjutnya, data dari kuestioner dan dokumentasi nilai UTS di uji menggunakan analisis regresi untuk mengetahui pengaruh implementasi ICT dalam pembelajaran terhadap hasil belajar bahasa Inggris siswa kelas XI di SMA se kabupaten Gorontalo.

Angket disusun sedemikian rupa berdasarkan indikator yang diukur. Angket yang digunakan adalah jenis angket tertutup sehingga responden tinggal memilih jawaban yang tersedia di angket. Angket disusun dengan menyiapkan 5 pilihan yakni sangat setuju, setuju, netral, tidak setuju, sangat tidak setuju. Setiap pilihan diberikan bobot nilai seperti pada table 2 .

Tabel 2. Bobot nilai Pernyataan menggunakan Skala Likert

\begin{tabular}{|c|c|}
\hline Pilihan & Bobot \\
\hline Sangat Setuju & 5 \\
\hline Setuju & 4 \\
\hline Netral & 3 \\
\hline Tidak Setuju & 2 \\
\hline Sangat Tidak setuju & 1 \\
\hline
\end{tabular}

Selanjutnya, nilai UTS siswa pada mata pelajaran bahasa Inggris didokumentasikan dan di nilai berdasarkan kriteria pada table 3. Selanjutnya, diuji apakah penggunaan ICT dalam pembelajaran berpengaruh positif terhadap hasil belajar bahasa Inggris siswa.

Tabel 3. Kriteria Hasil Belajar Siswa

\begin{tabular}{|l|l|}
\hline \multicolumn{1}{|c|}{ Interval Nilai } & \multicolumn{1}{c|}{ Kriteria } \\
\hline $86-100$ & Sangat baik \\
$71-85$ & Baik \\
$56-70$ & Cukup \\
$\leq 55$ & Kurang \\
\hline
\end{tabular}

Angket yangdigunakan dalam penelitian ini sudah diuji validitas dan reabilitas. Adapun kriteria pengujian validitas adalah dengan membandingkan nilai $\mathrm{r}_{\text {hitung }}$ dengan nilai $r_{\text {hitung. }}$
Jika, $r_{\text {hitung }}>r_{\text {tabel }}$ berarti Valid, sebaliknya $r_{\text {hitung }}<r_{\text {tabel }}$ berarti tidak Valid

Jumlah pernyataan yang digunakan untuk mengukur pengaruh implementasi ICT sebagai media dan sumber belajar dalam 
penelitian ini sebanyak 22 pernyataan yang diuji pada 40 siswa $(n=40)$, yang bukan Pengujian validitas pernyataan tersebut menjadi responden dalam penelitian ini. sebagai berikut:

Tabel 4. Hasil Uji Validitas Variabel Implementasi ICT sebagai Media dan Sumber Belajar

\begin{tabular}{|c|c|c|c|c|}
\hline Pernyataan & rHitung & $r_{\text {Tabel }}(n=40)$ & Keterangan & Status \\
\hline Butir-1 & 0,293 & & $\mathbf{r}_{\text {Hitung }}>\mathbf{r}_{\text {Tabel }}$ & Valid \\
\hline Butir-2 & 0,310 & & $\mathbf{r}_{\text {Hitung }}>\mathbf{r}_{\text {Tabel }}$ & Valid \\
\hline Butir -3 & 0,279 & & $\mathbf{r}_{\text {Hitung }}>\mathbf{r}_{\text {Tabel }}$ & Valid \\
\hline Butir -4 & 0,361 & & $\mathbf{r}_{\text {Hitung }}>\mathbf{r}_{\text {Tabel }}$ & Valid \\
\hline Butir -5 & 0,288 & & $\mathbf{r}_{\text {Hitung }}>\mathbf{r}_{\text {Tabel }}$ & Valid \\
\hline Butir -6 & 0,512 & & $\mathbf{r}_{\text {Hitung }}>\mathbf{r}_{\text {Tabel }}$ & Valid \\
\hline Butir -7 & 0,369 & & $\mathbf{r}_{\text {Hitung }}>\mathbf{r}_{\text {Tabel }}$ & Valid \\
\hline Butir -8 & 0,400 & & $\mathbf{r}_{\text {Hitung }}>\mathbf{r}_{\text {Tabel }}$ & Valid \\
\hline Butir -9 & 0,533 & & $\mathbf{r}_{\text {Hitung }}>\mathbf{r}_{\text {Tabel }}$ & Valid \\
\hline Butir -10 & 0,376 & $\begin{array}{c}\mathrm{df}=\mathrm{n}-2(40- \\
2=38)\end{array}$ & $\mathbf{r}_{\text {Hitung }}>\mathbf{r}_{\text {Tabel }}$ & Valid \\
\hline Butir -11 & 0,486 & & $\mathbf{r}_{\text {Hitung }}>\mathbf{r}_{\text {Tabel }}$ & Valid \\
\hline Butir -12 & 0,439 & 0,2638 & $\mathbf{r}_{\text {Hitung }}>\mathbf{r}_{\text {Tabel }}$ & Valid \\
\hline Butir -13 & 0,581 & & $\mathbf{r}_{\text {Hitung }}>\mathbf{r}_{\text {Tabel }}$ & Valid \\
\hline Butir -14 & 0,429 & & $\mathbf{r}_{\text {Hitung }}>\mathbf{r}_{\text {Tabel }}$ & Valid \\
\hline Butir -15 & 0,276 & & $\mathbf{r}_{\text {Hitung }}>\mathbf{r}_{\text {Tabel }}$ & Valid \\
\hline Butir -16 & 0,432 & & $\mathbf{r}_{\text {Hitung }}>\mathbf{r}_{\text {Tabel }}$ & Valid \\
\hline Butir -17 & 0,333 & & $\mathbf{r}_{\text {Hitung }}>\mathbf{r}_{\text {Tabel }}$ & Valid \\
\hline Butir -18 & 0,344 & & $\mathbf{r}_{\text {Hitung }}>\mathbf{r}_{\text {Tabel }}$ & Valid \\
\hline Butir -19 & 0,340 & & $\mathbf{r}_{\text {Hitung }}>\mathbf{r}_{\text {Tabel }}$ & Valid \\
\hline Butir -20 & 0,382 & & $\mathbf{r}_{\text {Hitung }}>\mathbf{r}_{\text {Tabel }}$ & Valid \\
\hline Butir- 21 & 0,486 & & $\mathbf{r}_{\text {Hitung }}>\mathbf{r}_{\text {Tabel }}$ & Valid \\
\hline Butir- 22 & 0,521 & & $\mathbf{r}_{\text {Hitung }}>\mathbf{r}_{\text {Tabel }}$ & Valid \\
\hline
\end{tabular}

Sumber: Data olahan SPSS 21, 2018

Dalam pengujian validitas, pernyataan dikatakan valid jika $r_{\text {hitung }}$ lebih besar dari $r_{\text {tabel. }}$ Nilai $r_{\text {tabel }}$ didapatkan dari tabel rho dimana $\mathrm{n}=40$ dan tingkat signifikan $5 \%$ maka nilai $\mathrm{r}_{\text {tabel }}$ sebesar 0.2638 . Dengan demikian dari 22 pernyataan yang digunakan untuk mengukur pengaruh dari variabel Implementasi ICT sebagai Media dan Sumber Belajar, semua pernyataan telah memiliki nilai $r_{\text {hitung }}$ lebih besar dari $r_{\text {tabel }}$ 0,2638 sehingga dikatakan memenuhi uji validitas dan dapat digunakan untuk pengumpulan data penelitian.

Kemudian uji reliabilitas dilakukan terhadap item pernyataan yang dinyatakan valid. Reliabilitas adalah indeks yang menunjukkan sejauh mana suatu alat ukur dipakai dua kali untuk mengukur gejala yang 
sama dan hasil pengukurannya relatif sama maka alat ukur tersebut reliabel. Pada penelitian ini, uji reliabilitas dilakukan dengan pendekatan internal consistency realibilty yang menggunakan tehnik alpha croncbach.

Pengambilan keputusan berdasarkan nilai alpha Cronbach jika nilai Alpha

\begin{tabular}{ccccc}
\hline Variabel & $\begin{array}{c}\text { Koefisien } \\
\text { Realibilitas }\end{array}$ & $\begin{array}{c}\text { Angka } \\
\text { Acuan }\end{array}$ & Keterangan & Status \\
\hline $\begin{array}{c}\text { Implementasi ICT } \\
\text { sebagai Media dan } \\
\text { Sumber Belajar }\end{array}$ & 0.695 & 0,6 & $\begin{array}{c}\text { Nilai Cronbah Alpa } \\
\text { lebih besar } \\
\text { dibandingkan dengan } \\
\text { nilai 0,6 }\end{array}$ & Reliabel \\
\hline
\end{tabular}

Sumber: Data Olahan SPSS 21, 2018

Berdasarkan hasil analisis dengan menggunakan teknik alpha croncbach sebagaimana yang disajikan pada tabel 5 di atas nilai koefisien reliabilitas sebesar 0,695 untuk variabel Implementasi ICT sebagai Media dan Sumber Belajar. Nilai koefisien Cronbach's Alpha tersebut lebih besar dari nilai patokan yang telah ditentukan yaitu 0.6. Hal ini menunjukan bahwa instrumen pernyataan dapat dipercaya dan dapat digunakan untuk penelitian selanjutnya. melebihi atau sama dengan 0.6 maka pernyataan variabel tersebut reliabel dan sebaliknya (Ghozali, 2005).

Hasil pengujian reliabilitas untuk variabel Implementasi ICT sebagai Media dan Sumber Belajar dapat disajikan berikut ini: 
Tabel 7. Kriteria Hasil Belajar Siswa

\begin{tabular}{|l|l|}
\hline \multicolumn{1}{|c|}{ Interval Nilai } & \multicolumn{1}{c|}{ Kriteria } \\
\hline $86-100$ & Sangat baik \\
$71-85$ & Baik \\
$56-70$ & Cukup \\
$\leq 55$ & Kurang \\
\hline
\end{tabular}

Selanjutnya analisis statistik tersebut, maka nilai koefisien korelasi (r) inferensial digunakan untuk menguji dapat dihitung dengan menggunakan hipotesis penelitian yang telah diajukan. persamaan koefisien korelasi product Pengujian hipotesis tersebut dimaksudkan momen. Kriteria yang digunakan untuk untuk mengetahui apakah penggunaan ICT menginterpretasi nilai kuatnya hubungan berpengaruh positif terhadap prestasi belajar antara kedua variabel adalah seperti yang Bahasa Inggris siswa SMA kelas XI di dikemukakan oleh Tiro (dalam Yusri, 2016), Kabupaten Gorontalo, berdasarkan nilai pada table 8. koefisien korelasi (r). Untuk maksud

Tabel 8. Kriterian Nilai Korelasi

\begin{tabular}{|l|l|}
\hline \multicolumn{1}{|c|}{ Nilai IHK } & \multicolumn{1}{c|}{ Hubungan } \\
\hline $0,80-1,00$ & Sangat kuat \\
$0,60-0,79$ & Kuat \\
$0,40-0,59$ & Sedang \\
$0,20-0,39$ & Lemah \\
\hline $0,00-0,19$ & Sangat lemah \\
\hline
\end{tabular}

\section{Hasil dan Pembahasan}

Responden dalam penelitian ini adalah siswa SMA kelas XI yang diambil dari tujuh SMA Negeri dan tiga SMA Swasta sebanyak 250 responden. Sebanyak 250 buah kuisioner yang disebarkan dan dapat diolah.
Sehingga tingkat pengembalian (response rate) yang diperoleh adalah $100 \%$. Data demografi responden dalam tabel 9 di bawah ini menyajikan beberapa informasi umum mengenai kondisi responden yang ditemukan di lapangan.

\section{Tabel 9. Informasi Umum Responden berdasarkan Jenis Kelamin}

\begin{tabular}{lcc}
\multicolumn{1}{c}{ Jenis Kelamin } & Jumlah Responden & Porsentase \\
\hline Laki- laki & 195 orang & $78 \%$ \\
\hline Perempuan & 55 orang & $22 \%$ \\
\hline \multicolumn{1}{c}{ Jurusan } & & \\
\hline XI IPA & 140 & $56 \%$ \\
\hline XI IPS & 78 & $31 \%$ \\
\hline XI Bahasa & 32 & $13 \%$ \\
\hline
\end{tabular}

Implementasi ICT sebagai Media dan Sumber Belajar dalam Pembelajaran Bahasa Inggris
Data tentang Implementsi ICT sebagai media dan sumber belajar dalam penelitian ini diperoleh dari angket dengan jumlah item 22 butir pernyataan 
menggunakan skala likert, skor yang digunakan dalam angket tersebut adalah 1 5. Nilai-nilai tersebut kemudian dikelompokan berdasarkan lima kategori, yaitu tidak baik, kurang baik, cukup baik, baik, dan sangat baik. Data skor penggunaan interent diolah dan dihitung prosentase masing masing dan diperoleh hasil sebagai berikut:

Tabel 10. Hasil Deskriptif Variabel Implementasi ICT

\begin{tabular}{|c|c|c|c|c|c|c|c|c|}
\hline \multirow{2}{*}{$\begin{array}{c}\text { Pernyataa } \\
\text { n }\end{array}$} & \multicolumn{5}{|c|}{ Alternatif Jawaban } & \multirow{2}{*}{$\begin{array}{c}\text { Skor } \\
\text { Actual } \\
\end{array}$} & \multirow{2}{*}{ \% Skor } & \multirow{2}{*}{ Kriteria } \\
\hline & $\mathbf{1}$ & 2 & 3 & 4 & 5 & & & \\
\hline 1 & 24 & 36 & 15 & 137 & 38 & 879 & $75 \%$ & Baik \\
\hline 2 & 56 & 109 & 3 & 54 & 28 & 639 & $48 \%$ & $\begin{array}{c}\text { Kurang } \\
\text { Baik }\end{array}$ \\
\hline 3 & 71 & 111 & 38 & 17 & 13 & 540 & $50 \%$ & $\begin{array}{c}\text { Kurang } \\
\text { Baik }\end{array}$ \\
\hline 4 & 11 & 92 & 85 & 47 & 15 & 713 & $58 \%$ & Cukup Baik \\
\hline 5 & 9 & 44 & 95 & 72 & 30 & 820 & $66 \%$ & Cukup Baik \\
\hline 6 & 0 & 1 & 27 & 120 & 102 & 1073 & $87 \%$ & Sangat Baik \\
\hline 7 & 0 & 5 & 57 & 128 & 60 & 993 & $78 \%$ & Baik \\
\hline 8 & 0 & 2 & 14 & 129 & 105 & 1087 & $88 \%$ & Sangat Baik \\
\hline 9 & 0 & 0 & 45 & 137 & 68 & 1023 & $82 \%$ & Baik \\
\hline 10 & 0 & 6 & 40 & 129 & 75 & 1023 & $82 \%$ & Baik \\
\hline 11 & 0 & 8 & 26 & 115 & 101 & 1059 & $84 \%$ & Baik \\
\hline 12 & 0 & 0 & 3 & 140 & 107 & 1104 & $95 \%$ & Sangat Baik \\
\hline 13 & 0 & 0 & 14 & 128 & 108 & 1094 & $89 \%$ & Sangat Baik \\
\hline 14 & 6 & 13 & 8 & 142 & 81 & 1029 & $82 \%$ & Baik \\
\hline 15 & 0 & 20 & 20 & 136 & 74 & 1014 & $81 \%$ & Baik \\
\hline 16 & 0 & 20 & 14 & 108 & 108 & 1054 & $84 \%$ & Sangat Baik \\
\hline 17 & 0 & 4 & 8 & 150 & 88 & 1072 & $86 \%$ & Sangat Baik \\
\hline 18 & 0 & 3 & 9 & 152 & 86 & 1071 & $86 \%$ & Sangat Baik \\
\hline 19 & 0 & 3 & 8 & 133 & 106 & 1092 & $88 \%$ & Sangat Baik \\
\hline 20 & 12 & 14 & 27 & 107 & 90 & 999 & $79 \%$ & Baik \\
\hline 21 & 0 & 3 & 21 & 143 & 83 & 1056 & $85 \%$ & Sangat Baik \\
\hline 22 & 10 & 26 & 25 & 130 & 59 & 952 & $76 \%$ & Baik \\
\hline \multicolumn{6}{|c|}{ Skor Variabel } & 972 & $78 \%$ & Baik \\
\hline
\end{tabular}

Secara keseluruhan persentase skor capaian untuk variabel Implementasi ICT sebagai Media dan sumber belajar dalam pembelajaran Bahasa Inggris adalah sebesar 972 satuan atau $78 \%$ dengan kategori baik. Hal ini menggambarkan bahwa siswa kelas XI SMA di Kabupaten Gorontalo setuju bahwa guru telah memanfaatkan ICT dengan baik dalam pembelajaran Bahasa Inggris, sehingga siswa merasa mudah dalam menerima materi ajar. Hal ini tentunya berakibat positif terhadap kemampuan siswa dalam pemahaman materi ajar Bahasa Inggris. Berikut ini dijelaskan secara rinci hasil analisis data pada masing-masing komponen implementasi ICT sebagai media dan sumber belajar dalam pembelajaran Bahasa Inggris 


\section{Penggunaan ICT sebagai Media Pembelajaran}

Data yang diperoleh dari komponen ini adalah sebesar $75 \%$ skor dengan criteria baik bahwa guru bahasa Inggris menggunakan ICT sebagai media dalam proses pembelajaran. Namun pada pernyataan ke dua mengenai penggunaan media yang bervariasi dalam pembelajaran diperoleh data hanya $48 \%$ skor dengan criteria kurang baik. Hal ini berarti bahwa secara keseluruhan guru telah menggunakan ICT sebagai media pembelajaran tetapi media ICT yang digunakan belum bervariasi.

\section{Pengembangan Media ICT}

Komponen ini terdiri dari pernytaan bahwa guru selalu meningkatkan kualitas media yang digunakan. Pada hasil analisis data diperoleh $50 \%$ dengan criteria kurang baik. Ini berarti guru bahasa Inggris kurang memperhatikan kualitas media yang digunakan untuk mentranfer materi kepada siswa. Selanjutnya, mengenai pernyataan guru mengkombinasikan satu media belajar dengan media belajar lainnya memperoleh skor 58\% dengan indicator cukup baik. Dapat disimpulkan bahwa hasil ini berkaitan erat dengan data sebelumnya yaitu media ICT yang digunakan belum bervariasi sehingga guru belum bisa mengkolaborasikan satu media dengan media yang lain.

\section{Kriteria Media Pembelajaran ICT}

Dari komponen ini diperoleh data bahwa media ICT yang digunakan cukup menarik dibuktikan dengan skor 66\% yaitu cukup baik. Selanjutnya, pada pernyataan bahwa media ICT mudah digunakan oleh siswa diperoleh skor $87 \%$ dengan indicator angat baik. Mengenai keterampilan guru dalam menggunakan media ICT memperoleh skor $78 \%$ dengan indicator baik. Dengan demikian, dapat disimpulkan bahwa media yang digunakan memudahkan siswa selama proses belajar, para guru juga telah memiliki kemampuan menggunakan media ICT yang baik, dan media yang digunakan dalam pembelajaran bahasa Inggris sejauh ini cukup baik.

\section{Fungsi Media Pembelajaran ICT}

Media pembelajaran dengan

memanfaatkan ICT dipercaya dapat memotivasi siswa dalam belajar, hal ini dibuktikan dengan data bahwa pada pernyataan media ICT memberikan motivasi kepada siswa memperoleh skor $88 \%$ dengan kategori sangat baik. Pemahaman atau keterampilan siswa juga meningkat ketika guru memanfaatkan media ICT dilihat dengan skor $82 \%$ dalam kategori baik. Kesimpulannya, siswa SMA kelas XI merasa bahwa ketika guru menggunakan media ICT dalam pembelajaran mereka termotivasi dan pemahaman serta keterampilan bahasa Inggris meningkat.

\section{Manfaat Media Pembelajaran ICT}

Dari hasil analisis data diperoleh bahwa media ICT memberikan manfaat kepada siswa berupa keterlibatan secara aktif selama pembelajaran dengan skor $82 \%$ pada kategori baik. Manfaat lainnya adalah siswa merasa lebih mudah memahami materi yang dijelaskan guru dengan skor $84 \%$ kategori baik.

Selain itu media ICT juga dirasakan manfaatnya oleh siswa dalam hal memberikan pengalaman belajar yang lebih baik dibandingkan dengan hanya membaca buku teks. Ini dibuktikan dengan skor 95\% kategori sangat baik. Selanjutnya, siswa juga merasa pembelajaran menjadi lebih menarik ketika guru menggunakan media ICT dengan skor $89 \%$ pada kategori sangat baik.

\section{Penggunaan ICT sebagai sumber belajar}

Dari hasil analisis data menunjukkan bahwa guru memberikan kesempatan kepada siswa untuk mengakses internet untuk mencari materi dengan skor $82 \%$ kategori baik. Ini berarti penggunaan internet oleh siswa sebagai sumber belajar untuk mencari referensi atau materi belajar sudah baik.

7. Kriteria Sumber Belajar ICT 
Data yang diperoleh untuk komponen ini bahwa guru memberikan akses link/tautan yang menarik kepada siswa untuk digunakan mencari materi. Hasil ini memperoleh skor $81 \%$ dengan kategori baik. Guru juga memberikan link/tautan yang mudah diakses oleh siswa dengan perolehan skor 84\% kategori sangat baik. Hal ini menunjukkan internet sebagai sumber belajar online memudahkan siswa untuk mengakses materi belajar yang menarik.

\section{Fungsi Sumber Belajar ICT}

Dari hasil analisis data diperoleh bahwa siswa merasa termotivasi untuk mempelajari materi ketika terbantu dengan internet. Data ini memperoleh skor 86\% dengan kategori sangat baik. Siswa juga mudah memahami materi ketika memanfaatkan internet dalam pembelajran dengan skor $86 \%$ pada kategori sangat baik. Selain itu siswa juga menjadi lebih aktif dalam proses pembelajaran dengan skor $88 \%$ atau sangat baik. Kesimpulannya, sebagian besar responden dalam penelitian setuju bahwa internet membuat mereka termotivasi, mudah memahami materi, dan menjadi lebih aktif selama pembelajaran Bahasa Inggris.

\section{Manfaat Sumber Belajar ICT}

Dengan memanfaatkan internet sebagai sumber belajar siswa merasa lebih mudah mendapatkan materi belajar dibuktikan dengan skor $79 \%$ atau kategori baik, materi yang diperoleh dari internet menjadi bervariasi dengan skor $85 \%$ atau kategori sangat baik, serta internet membantu menyelesaikan tugas sekolah dengan skor 76\% atau kategori baik. Dengan demikian manfaat yang dirasakan dari implementasi internet sebagai sumber belajar telah dirasakan oleh sebagian besar siswa dengan baik.

\section{Hasil Belajar Siswa dalam Mata Pelajaran Bahasa Inggris}

Hasil belajar dapat didefinisikan sebagai suatu bukti keberhasilan belajar atau kemampuan seseorang siswa dalam melakukan kegiatan belajarnya sesuai dengan bobot yang dicapainya. Sedangkan menurut Nasution (dalam Yusri, 2016) prestasi atau hasil belajar adalah: "Kesempurnaan yang dicapai seseorang dalam berfikir, merasa dan berbuat. Dengan demikian hasil belajar bahasa Inggris siswa bisa diperoleh dari bobot nilai yang merupakan bukti dari proses kegiatan belajar bahasa Inggris.

Dari hasil analisis hasil belajar siswa yang diperoleh dari nilai Ujian Tengah Semester semester genap 2017/2018 menunjukkan bahwa hasil belajar siswa kelas XI pada mata pelajaran Bahasa Inggris adalah baik dengan prosentase $78.8 \%$ dengan jumlah responden 197 siswa, dan sangat baik dengan $20.4 \%$ responden yakni 51 siswa, (lihat gambar 1). Dengan demikian, dapat disimpulkan bahwa hasil belajar siswa kelas XI pada mata pelajaran Bahasa Inggris ada dalam kategori baik. 


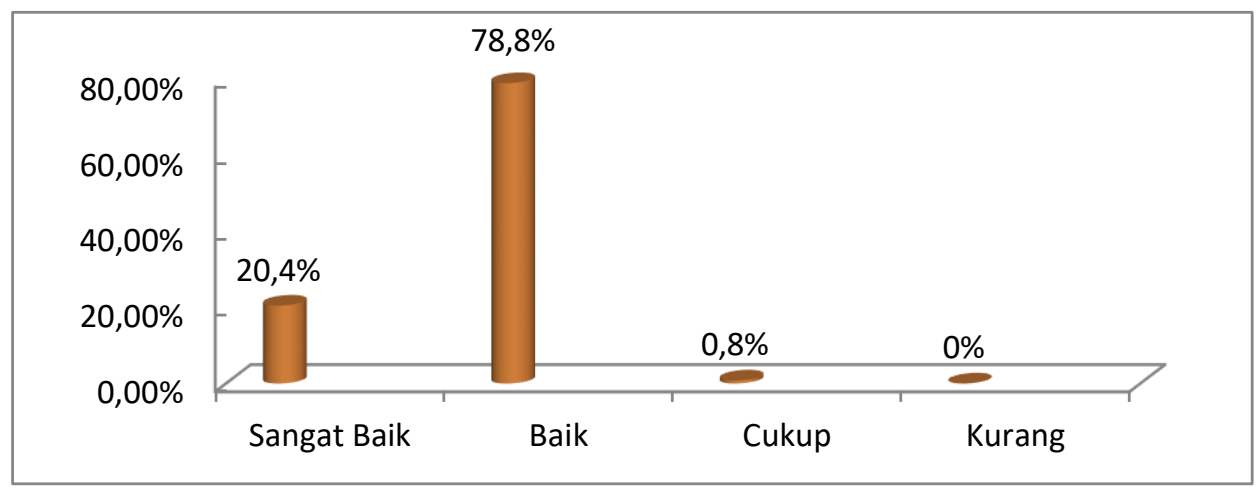

Gambar 1. Diagram Hasil Belajar Siswa Kelas XI

Pengaruh Implementasi ICT sebagai

Media dan Sumber Belajar dalam

Pembelajaran Bahasa Inggris terhadap Hasil Belajar Siswa

Analisis yang dilakukan dengan korelasi Product Moment (rxy) antara implementasi ICT (X) dengan hasil belajar siswa kelas XI (Y) diperoleh koefisien korelasi sebesar 0.604 nilai yang kuat. Hasil ini menunjukkan hubungan dan pengaruh positif dan signifikan antara Implementasi
ICT sebagai media dan sumber belajar dalam pembelajaran Bahasa Inggris dengan hasil belajar Bahasa Inggris siswa kelas XI. Nilai $\mathrm{R}$ Square atau nilai koefisiensi determinasi sebesar 0,365 yang berarti bahwa variabel dependen (Hasil Belajar) mampu dijelaskan oleh variabel independen (Implementasi ICT), sebesar 36,5\%, sebaliknya sebesar $63,5 \%$ dapat dijelaskan oleh faktor-faktor lain yang tidak diikutsertakan dalam penelitian ini.

\begin{tabular}{|r|r|r|}
\hline \multicolumn{2}{c}{} & \multicolumn{2}{c|}{ Model Summary } \\
\hline R Square & $\begin{array}{c}\text { Adjusted R } \\
\text { Square }\end{array}$ & $\begin{array}{c}\text { Std. Error of } \\
\text { the Estimate }\end{array}$ \\
\hline .365 & .363 & 4.29042 \\
\hline
\end{tabular}

Analisis regresi sederhana digunakan untuk melihat pengaruh variabel bebas terhadap variabel terikat serta memprediksi nilai variabel terikat dengan menggunakan variabel bebas. Setelah dilakukan uji asumsi normalitas dan ternyata dipenuhi, tahap selanjutnya dilakukan pemodelan data dengan menggunakan analisis regresi sederhana. Pengujian hipotesis ini dilakukan melalui tahapan-tahapan untuk mencari persamaan regresi.

Dalam perhitungan persamaan regresi, digunakan suatu persamaan umum yaitu:

$$
\hat{\mathrm{Y}}=\mathrm{a}+\mathrm{bX}
$$

Hasil perhitungan regresi dengan menggunakan program SPSS 21 disajikan dalam tabel dibawah ini: 


\section{Coefficients $^{\mathrm{a}}$}

\begin{tabular}{|rl|r|r|r|r|r|}
\hline \multirow{2}{*}{ Model } & \multicolumn{2}{|c|}{$\begin{array}{c}\text { Unstandardized } \\
\text { Coefficients }\end{array}$} & $\begin{array}{c}\text { Standardized } \\
\text { Coefficients }\end{array}$ & \multirow{2}{*}{ Sig. } & \\
\cline { 2 - 5 } & \multicolumn{1}{|c|}{$\mathrm{B}$} & \multicolumn{1}{c|}{ Std. Error } & \multicolumn{1}{c|}{ Beta } & & \\
\hline \multirow{2}{*}{$1 \quad$ (Constant) } & 38.690 & 3.561 & & 10.865 & .000 \\
& Implementasi & .501 & .042 & .604 & 11.942 & .000 \\
\hline
\end{tabular}

Sumber: Data Olahan 2018

$$
\begin{gathered}
\hat{\mathbf{Y}}=\mathbf{3 8 , 6 9 0}+\mathbf{0 , 5 0 1} \mathrm{X} \\
\text { Hasil Belajar }=\mathbf{3 8 , 6 9 0}+\mathbf{0 , 5 0 1} \\
\text { Implementasi ICT }
\end{gathered}
$$

Berdasarkan model persamaan regresi tersebut, maka dapat diinterpretasikan hal-hal sebagai berikut:

a. Nilai Koefisien Regresi Variabel $\mathrm{X}$ (Implementasi ICT), menunjukan setiap peningkatan variabel Implementasi ICT sebesar 1 satuan maka Hasil Belajar sebesar mengalami peningkatan (sebab koefisien positif) sebesar 0,501 kali satuan.

b. Nilai Koefisien regresi dengan arah postif menunjukan terdapat pengaruh yang positif Implementasi ICT sebagai media dan sumber belajar terhadap Hasil Belajar Mata pelajaran Bahasa Inggris pada siswa kelas XI SMA di Kabupaten Gorontalo

Hasil analisis di atas menunjukan bahwa nilai t-hitung untuk variabel Implementasi ICT diperoleh sebesar 11,942, sedangkan nilai $t_{\text {-tabel }}$ pada tingkat signfikansi $5 \%$ dan derajat bebas n-k-1 $=250-1-1=248$ sebesar 1,971. Jika kedua nilai $t$ ini dibandingkan maka nilai t-hitung masih lebih besar dibandingkan dengan nilai $t$-tabel (11.942>1,971) sehingga $\mathrm{H}_{0}$ ditolak dan $\mathrm{H}_{1}$ diterima. Selain itu apabila kita membandingkan nilai signifikansi atau Probability $\left(\mathrm{P}_{\text {value }}\right)$, maka dapat dilihat bahwa nilai Probability atau $\mathrm{P}_{\text {value }}(0,000)$ dari pengujian ini lebih kecil dari 0.05. Dengan kata lain dapat disimpulkan bahwa terdapat pengaruh yang signifikan dari Implementasi ICT sebagai Media dan Sumber belajar dalam pembelajaran Bahasa Inggris terhadap Hasil Belajar Bahasa Inggris Siswa SMA kelas XI di Kabupaten Gorontalo.

Pernyataan dan hasil di atas didukung juga oleh beberapa hasil penelitian. Yusri (2016) dimana menunjukkan hasil bahwa penggunaan TIK/ICT memiliki manfaat yang sangat besar terhadap peningkatan penguasaan media internet oleh para pendidik dalam memotivasi peserta didik kelas X SMA Negeri I Dekai Kabupaten Yahukimo. Semakin baik kualitas penggunaan TIK/ICT pada mata pelajaran Bahasa Inggris maka semakin meningkat pula hasil belajar Bahasa Inggris siswa.

Sabar \& Rahman (2011) melalui penelitian yang dilaksanakan di Briton International School Makassar. Hasil yang diperoleh yaitu (a) para siswa mendapatkan lebih banyak informasi dan bahan belajar yang terkini (up to date) dengan mudah, lebih cepat dan detail (jelas), dan menarik. (b) Keterampilan berbahasa Inggris para siswa dapat berkembang khususnya keterampilan reading, writing,vocabulary, dan grammar, (c) Para siswa lebih aktif dan bersemangat karena terlibat langsung dalam proses mendapatkan informasi dan bahan belajar yang dibutuhkan dalam pembelajaran 
Bahasa Inggris. Kariman \& Mulia (2012) menguji efektifitas pemanfaatan web blog dalam pembelajaran Bahasa Inggris. Pembelajaran dengan media weblog dapat meningkatkan hasil belajar siswa.

\section{Kesimpulan}

Berdasarkan hasil dan pembahasan sebelumnya, maka dapat disimpulkan bahwa ada hubungan dan pengaruh positif signifikan antara implementasi ICT sebagai media dan sumber belajar pada pembeljaran bahasa inggris dengan hasil belajar Bahasa Inggris siswa SMA kelas XI di Kabupaten Gorontalo.

Hasil analisis data mengenai persepsi siswa kelas XI tentang implementasi ICT pada pembelajaran yaitu secara keseluruhan persentase skor capaian untuk variabel Implementasi ICT sebagai Media dan sumber belajar dalam pembelajaran Bahasa Inggris adalah sebesar 972 satuan atau $78 \%$ dengan kategori baik. Hal ini menggambarkan bahwa siswa kelas XI SMA di Kabupaten Gorontalo setuju bahwa guru telah memanfaatkan ICT dengan baik dalam pembelajaran Bahasa Inggris, sehingga siswa merasa mudah dalam menerima materi ajar. Hal ini tentunya berakibat positif terhadap kemampuan siswa dalam pemahaman materi ajar Bahasa Inggris.

Hasil belajar siswa kelas XI pada mata pelajaran Bahasa Inggris adalah baik dengan prosentase $78.8 \%$ dengan jumlah responden 197 siswa, dan sangat baik dengan $20.4 \%$ responden yakni 51 siswa. Dengan demikian, dapat disimpulkan bahwa hasil belajar siswa kelas XI pada mata pelajaran Bahasa Inggri ada dalam kategori baik.

Analisis yang dilakukan dengan korelasi Product Moment (rxy) mengenai implementasi ICT (X) dengan hasil belajar siswa kelas XI (Y) diperoleh koefisien korelasi sebesar 0.604 (nilai yang kuat). Hasil ini menunjukkan hubungan dan pengaruh positif dan signifikan antara Implementasi ICT sebagai media dan sumber belajar dalam pembelajaran Bahasa Inggris dengan hasil belajar Bahasa Inggris siswa kelas XI. Nilai $R$ Square atau nilai koefisiensi determinasi sebesar 0,365 yang berarti bahwa variabel dependen (Hasil Belajar) mampu dijelaskan atau dipengaruhi oleh variabel independen (Implementasi ICT), sebesar 36,5\%, sebaliknya sebesar $63,5 \%$ dapat dijelaskan oleh faktor-faktor lain yang tidak diikutsertakan dalam penelitian ini.

Pada akhirnya, guru Bahasa Inggris diharapkan mampu mengembangkan keterampilan dalam menggunakan media ICT yang lebih bervariasi dengan mengikuti workshop pengembangan media dan sumber belajar berbasis ICT. Peneliti selanjutnya yang tertarik dengan topic yang sama dengan penelitian ini diharapkan untuk mengembangkan penelitian ini ke ranah penemuan model pembelajaran berbasis ICT untuk siswa SMA, karena telah terbukti bahwa ICT secara positif signifikan memiliki hubungan dan pengaruh terhadap hasil belajar siswa terutama dalam mata pelajaran Bahasa Inggris.

\section{DAFTAR PUSTAKA}

Cahyono, B. Y., \& Widiati, U. 2007. Challenges and Possibilities in the Integration of the Internet in English Language Teacher Education. In M. K. Kabilan \& M. E. Venthamani (Eds.), Internet and the English Language Classroom (pp. 187-209). Petaling Jaya, Malaysia: Sasbandi Sdn Bhd.

Cahyono, Bambang Yudi. 2011. Best Practices in the Teaching of English. State University of Malang: Malang. Kariman, T. M., \& Eddy M. 2012. Pemanfaatan Weblog sebagai Media Pembelajaran untuk Meningkatkan Hasil Belajar Bahasa Inggris. Jurnal 
Teknologi Pendidikan, Vol. 5 No. 1 (hal. 72-86)

Sabar, K. \& Asfah, R. 2011. Penggunaan Web (e-learning) Dalam Proses Pembelajaran Bahasa Inggris Di briton International English School Makassar. Jurnal Komunikasi KAREBA Vol. 1, No. 4 (hal. $444-456$ ).

Sudrajat, D., \& Permatasari, H. 2013. Pembelajaran Multimedia Untuk Meningkatkan Kualitas Belajar Siswa Dalam Mempelajari Materi Bahasa Inggris Kelas XI IPS Menggunakan Macromedia Flash MX Di MAN 2 Kota Cirebon. Jurnal Online ICT STMIK IKMI Vol. 1-No. 1 (hal. 1-15)

Yusri. 2016. Pengaruh Penggunaan Media Teknologi Informasi Dan Komunikasi (TIK) Dengan Prestasi Belajar Bahasa Inggris Peserta Didik Kelas X Di Sman I Dekai Kabupaten Yahukimo. Jurnal Ilmiah ILKOM Vol 8 No 1 (hal.49-56) 